\title{
Physico-chemical attributes and organoleptic assessment of guava (Psidium guajava L.) cultivars grown in eastern Uttar Pradesh
}

\author{
Anupam Tiwari", A. K. Pal, Sarvesh Singh, S. P. Singh and Vishnu lal Patidar \\ Department of Horticulture, Institute of Agricultural Sciences, Banaras Hindu University, Varanasi- 221005 (U.P.), INDIA \\ *Corresponding author. E-mail: uniquetiwari77@gmail.com
}

Received: September 29, 2015; Revised received: June 24, 2016; Accepted: September 20, 2016

\begin{abstract}
A study was conducted to evaluate the different guava cultivars for their physico-chemical composition and organoleptic assessment during the year 2012-2013. Results of study indicated that Gorakh Bilas Pasand cultivar proved to be superior on the basis of physical characters (Length-7.64 cm, Breadth-7.79 cm , Weight-240.60 g, Number of seeds per fruit-251 etc.) followed by Lucknow-49. However, Lucknow-49 was found noteworthy in respect of chemical composition (TSS- $13.00^{\circ}$ Brix, Acidity- $0.50 \%, \mathrm{pH}-5.86$, Vitamin C-300.36 mg/100g etc). In organoleptic assessment, it was found that 'liked very much' rating was provided by consumer to Lucknow-49. On the basis of overall findings, it was concluded that 'Lucknow-49' was superior in most of characters studied and might be one of the promising cultivars for quality fruits under eastern Uttar Pradesh conditions.
\end{abstract}

Keywords: Guava, Lucknow-49, Organoleptic assessment, Shelf life, Vitamin C

\section{INTRODUCTION}

Guava (Psidium guajava L.) is cultivated in many tropical and subtropical countries for its nutritious fruits and has become naturalized in several countries. The fruits are of economic importance and whole fruit utilized in one or other way. On account of wider adaptability, tolerance to various stresses and high productivity coupled with low input requirements and high nutritive value on cheaper rate, the demand of this fruit remains high not only in fresh form but also in form of processed products (Bal et al., 2014). This fruit has high demand in preservation industry for preparation of jelly, candy, nectar and mixed jam due to its qualitative physico-chemical attributes and organoleptic scores (Karla and Tandon, 1984). However, the information on physico-chemical attributes along with acceptability of different cultivars based on organoleptic assessment is lacking. in different fruits of eastern Uttar Pradesh cultivars is infrequent. For each fruit typically there were different cultivars and among them few may contain one or various native substances (Siddiq, 2012). Furthermore this is the established fact that fruits which was rich in vitamins and minerals their processed products should also rich in vitamins and minerals.

Therefore, the present investigation was carried out to evaluate guava cultivars grown in eastern Uttar Pradesh to find out the cultivars which are qualitatively superior and high in physico-chemical attributes and organoleptic scores.

\section{MATERIALS AND METHODS}

The experiment was conducted during 2012-13 in the Post-Harvest laboratory, Department of Horticulture, Institute of Agricultural Sciences, Banaras Hindu University, Varanasi, on five cultivars of guava viz., Lucknow-49, Allahabad Safeda, Lalit, Shweta and Gorakh Bilas pasand.

Ten fruits were selected randomly from all the directions of these ten trees of every cultivars for quantitative and qualitative attributes of fruit like fruit weight, length, width, fruit volume, pericarp thickness, total number of seeds, seed index, number of seed/hundred gram of fruit weight, total Soluble Solids, acidity, $\mathrm{pH}$, and vitamin $\mathrm{C}$. The fresh, fully ripened and uniform sized fruits having greenish yellow colour were procured during the winter season (2012-13). The trees were of uniform size and vigor and were kept under uniform cultural practices during the experimental period. Length and thickness of fruit was measured by using digital vernier calipers. Fruit volume was determined by water displaced method where as fruit weight was measured with electronic balance. The pulp colour was described with the help of Exotica Horticultural colour guide (Graf, 1982). Number of seeds per fruit was calculated by separating the seeds by using ordinary sieve $(<20 \mathrm{~mm})$ and then counting of seeds per fruit was accomplished. Specific gravity of fruits was calculated by the formula as used by Singh et al. (2013). For chemical analysis of the fruits viz., TSS, ascorbic acid, $\mathrm{pH}$ and titrable acidity was 
done following methods as described by AOAC (1990). Organoleptic evaluation by 6 panelist was carried out using a nine-point hedonic scale (1 dislike extremely 9 like extremely). Water was provided to the testers to rinse their month after each evaluation under a well lighted evaluation room (Amerine et al., 1965). The data collected during the course of investigation were analysed following complete randomized design (Panse and Sukhatme, 1985).

\section{RESULTS AND DISCUSSION}

Physical characters of different cultivars of guava: The cultivars differed in shape and most of them had roundish appearance. The fruit shape varied from roundish ovate (L-49) to globose (Shweta). Skin colour of fruit varied from primrose yellow (L- 49) to creamy white (Shweta) among cultivars. Flesh color of Lalit was pink, which was quite different among evaluated cultivars, whereas flesh colour of Shweta was snow white. A significant varietal variation in fruit length was observed in guava (Table 1). The fruit length varied between $6.47 \mathrm{~cm}$ to $7.64 \mathrm{~cm}$ among cultivars studied. Gorakh Bilas Pasand produced longest $(7.64 \mathrm{~cm})$ fruit length followed by L-49 $(7.52 \mathrm{~cm})$ and Allahabad Safeda $(6.94 \mathrm{~cm})$. Similar trend was also found in fruit width and among the cultivars, Gorakh Bilas Pasand produced the maximum fruit breadth $(7.79 \mathrm{~cm})$ followed by L-49 $(7.52 \mathrm{~cm})$ and Allahabad Safeda (7.41 $\mathrm{cm})$. A significant variation was noted in thickness of pericarp and thickness of placenta among the cultivars. Gorakh Bilas pasand had maximum thickness of placenta $(4.38 \mathrm{~cm})$ and pericarp $(1.75 \mathrm{~cm})$, while minimum thickness of placenta $(1.24 \mathrm{~cm})$ and pericarp $(3.66 \mathrm{~cm})$ was noted in Lalit. The variation in fruit size can be attributed to genetic constitution of the varieties. Ratanpal et al. (2002) observed that L-49 showed the highest fruit length, weight and volume, while Singh et al. (2013) reported that higher fruit length was observed in Hisar Surkha which closely followed by L-49 and Lalit. The weight, volume and specific gravity are directly related to size of the fruit. The maximum fruit weight $(240.60 \mathrm{~g})$ and volume $(234.31 \mathrm{ml})$ was observed in Gorakh Bilas Pasand while the minimum fruit weight $(172.96 \mathrm{~g})$ and volume (170.94 g) was recorded in Lalit (Table 1).

The specific gravity of guava ranged from 0.99 to 1.02 and it was observed maximum in Gorakh Bilas Pasand, and minimum in Lalit. The similar results were connoted by Raghav and Tiwari (2008). The minimum number of seeds per hundred grams of fruits was observed in Gorakh Bilas Pasand (117.00), whereas the maximum seed count (151.33) was recorded in Lalit. Though, Lalit showed the maximum number of seeds yet the seed weight was the lowest and soft in nature. Variation showed in characters of seed (seed texture, seed index and seed/100 g fruit) may be attributed to genetic makeup of the plants. In connection to this
Singh and Singh (2000) observed variations in seed characters of guava fruit and annotated that total seed weight per fruit was maximum in Allahabad Safeda which in addition strengthen the results recorded by Marak and Mukunda (2007) and Patel et al. (2007) where the weight of 100 seed range between $0.29 \mathrm{~g}$ in Allahabad Safeda which was higher in comparison to other cultivars.

The maximum shelf life was observed L- 49 was (8.3 days) while it was (6.50) days in Lalit at room temperature (Table 1). Per cent physiological weight loss of guava was observed at 4 and 8 days after harvesting. The maximum value $(9.22 \%)$ of physiological loss was observed in cv. Lalit whereas minimum physiological loss $(4.42 \%)$ was found in Gorakh Bilas Pasand followed by L-49 (5.14 \%). These results are in concurrence with the findings of Islam et al. (2008) in which the cultivar Kazi showed physiological loss in same way. The highest dry matter content $(17.30 \%)$ of fruit was noted in L-49, while it was lowest $(15.10 \%)$ in Allahabad Safeda. The maximum pulp per cent (55.09) was noted in Lalit, though minimum pulp recovery per cent (52.36) was observed in Gorakh Bilas Pasand (Kaur et al., 2008).

Chemical composition of different cultivars of guava: A highly significant difference in acid content of fruit was recorded among various cultivars during winter season. The highest $(0.63 \%)$ acidity was found in cv. Allahabad Safeda followed by Shweta $(0.57 \%)$ and Lalit $(0.53 \%)$. These results were in conformity with the findings of Singh et al. (2013) in which the acidity range was highest in Shweta and lowest in Lalit. L-49 established its supremacy for total soluble solids (TSS) content over the other cultivars. The highest TSS $\left(13^{\circ}\right.$ Brix $)$ were recorded with L-49, while it was the lowest $\left(11.17^{\circ}\right.$ Brix $)$ in Gorakh Bilas Pasand. It may be due to phenotypic and genetic constitution of the cultivar which might have necessitated consumption of nutrients and diverting more carbohydrates into the fruits. This in turns might have produced larger fruits with more TSS.

The maximum (26.02) TSS/acid ratio observed in L49, while minimum (18.63) was counted in Allahabad Safeda. The ascorbic acid content was observed highest in L-49 in both pericarp (300.36 mg/100 g) and placenta $(249.27 \mathrm{mg} / 100 \mathrm{~g})$, while fruits of Lalit produced lowest value $(188.20 \mathrm{mg} / 100 \mathrm{~g}$ in pericarp) and (166.00 mg/100 $\mathrm{g}$ in placenta) Table 2 . The variation in ascorbic acid content may be ascribed as a varietal character. Mahour et al. (2012) reported that L-49 was superior in terms Vitamin C content as compare to other cultivars. Fruits of cv. L-49 exhibited highest (5.86) pH while it was the lowest (5.40) in cv. Lalit. Chaoudhari et al. (2012) also found the highest $\mathrm{pH}$ in L-49.

Organoleptic assessment: The main criterion for fixing the market prices of any produce is the quality. This depends greatly on sensory evaluation by experi- 


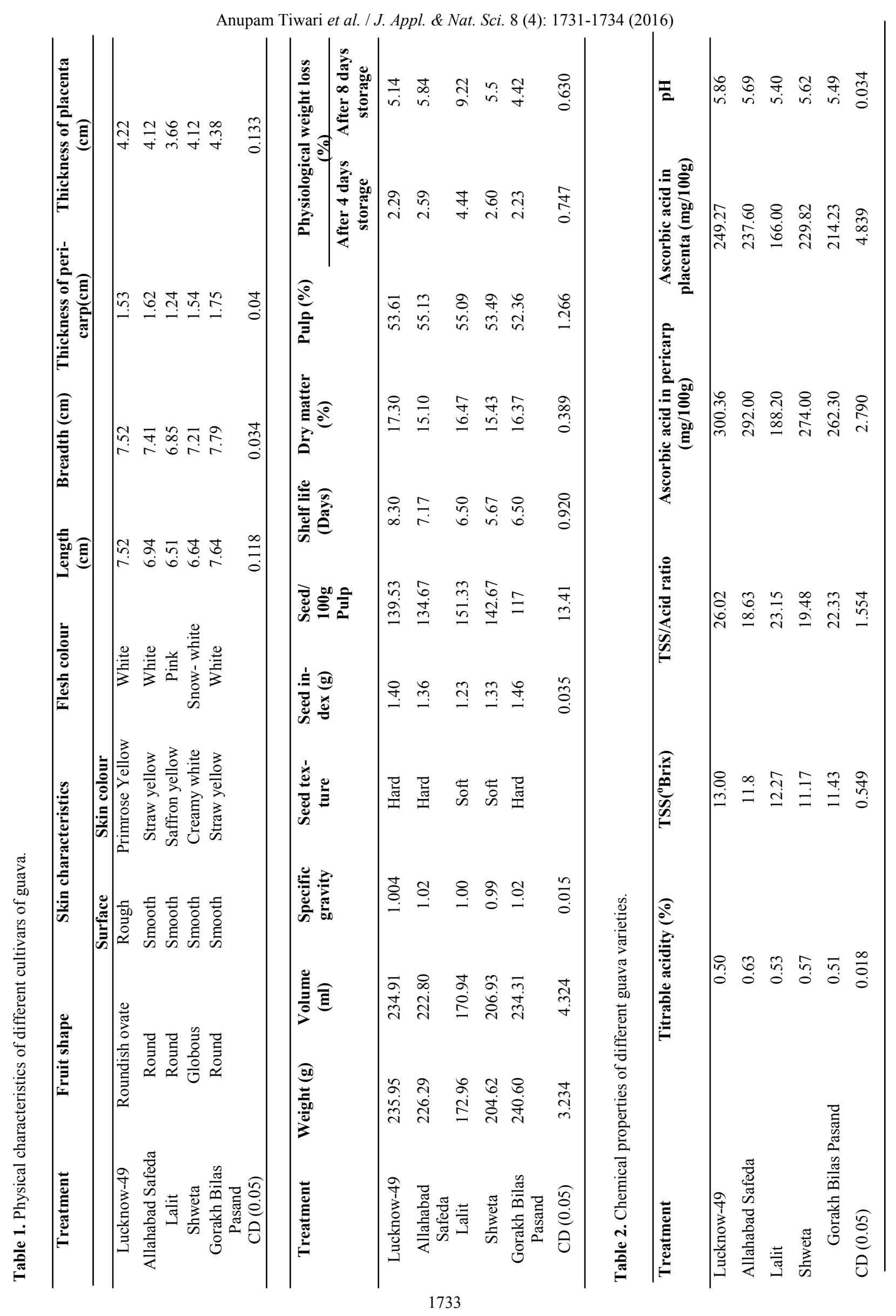


Table 3. Organoleptic assessment of guava cultivars.

\begin{tabular}{lccccc}
\hline \multicolumn{1}{c}{ Treatment } & Colour & Taste & Flavour & Texture & $\begin{array}{c}\text { Overall acceptability } \\
\text { (mean) }\end{array}$ \\
\hline Lucknow-49 & 8 & 9 & 8.5 & 9 & 8.63 \\
Allahabad Safeda & 8.2 & 8.5 & 8.3 & 8.6 & 8.40 \\
Lalit & 9 & 8.2 & 8.2 & 8.4 & 8.45 \\
Shweta & 7.8 & 8.2 & 8.6 & 8.6 & 8.30 \\
GorakhBilas Pasand & 7.6 & 8 & 8 & 8.2 & 7.95 \\
\hline
\end{tabular}

*Data presented in table are average of the marks given by 6 judges out of 9 .

enced judges. The results of present investigation revealed that the consumer rated maximum for cultivar $\mathrm{L}$ -49 (8.63) followed by cv. Lalit (8.45) and cv. Allahabad Safeda (8.40). The reason for maximum scoring of L-49may be due to appeal appearance, delightful flavor and pleasing taste.

\section{Conclusion}

Results of present investigation revealed that Gorakh Bilas Pasand proved to be superior to Lucknow-49 on the basis of physical characters, whereas Lucknow-49 was found superior with regards to chemical composition. In organoleptic assessment it was found that the consumer rated liked very much for Lucknow-49. On the basis of foregoing findings, it was concluded that 'Lucknow-49' was superior in most of characters studied and may be one of the promising cultivars for quality fruits production under eastern Uttar Pradesh.

\section{REFERENCES}

Amerine, M. A., Pangborn,R. M., and Roessler, E. B. (1965). Principles of sensory evaluation of food. In: Food Science and Technology Monographs. Academic Press, New York Pp, 338-339

Anonymous (1990). Method of analysis of the association of official agricultural chemist, washington, D.C., USA.

Bal, L. M., Ahmad, T., Senapati, A. K. and Pandit, P.S. (2014). Evaluation of quality attributes during storage of guava nectar cv. Lalit from different pulp and tss ratio. J Food Process Technol, 5: 329

Choudhary, M. L. Dikshit, S. N., Shukla, N. and Saxena, R. R. (2012). Studies on physico-chemical properties of different guava varieties under agro-climatic conditions of Chhattisgarh plains. Prog. Hort., 44(2):340-341

Graf, A. B. (1982). Exotica int. pictorial cyclopedia exotic plants. Rochrs company, east rutherford, New Jersey USA. Series 4, Vol. II. pp. 1836-1837
Islam, F., Islam, A., Mansur, M.A. and Rahim, M.A. (2008). Shelf life and quality of guava cv. kazi as affected by stages of ripening, storage temperature and wrapping materials. Prog. Agric. J., 19(2): 1-12

Kalra, S.K. and Tandon, D. K. (1984). Guava nectars from sulphited pulp and their blends with mango nectar. Indian Food Packer, 38: 74-77

Kaur, S., Shankar, B.C., Sharma, H. K. and Singh C. (2008). Optimization of enzymatic hydrolysis pretreatment conditions for enhanced juice recovery from guava fruit using surface methodology. Food and Bioprocess Tech., 2(1): $96-100$

Mahour, M. K., Tiwari, R. and Baghel, B. S. (2012). Physico-chemical characteristics of different varieties/ germplasm of guava in malwa plateau of Madhya Pradesh. Agri. Sci. Digest, 32 (2): 141 - 144

Marak, J. K. and Mukunda, G. K. (2007). Studies on the performance of open pollinated seedling progenies of guava $c v$. Apple Colour. Acta Hort., 735: 79-84

Panse, V.G. and Sukhmate, P. V. (1985). Statistical methods for agricultural workers, $4^{\text {th }}$ Edn. ICAR, New Delhi.

Patel, R. K., Yadav, D. S., Babu, K. D., Singh, A. and Yadav, R. M. (2007). Growth, yield and quality of various guava (Psidium guajava L.) Hybrids / cultivars under mid hills of Meghalaya. Acta Hort., 735: 57- 59

Raghav, M. and Tiwari, J. P. (2008). Genetic variability and correlation analysis in guava. Indian J. Hort., 65 (3): 263-270

Ratanpal, H. S. and Dhaliwal, G. S. (2002). Studies on new introduction of guava at Ludhiana. J. of Res., 39 (2):190196

Siddiq, M. \& Nasir, M. (2012). Tropical and subtropical fruits: postharvest physiology, processing and packaging. Wiley-Blackwell, 587-596

Singh, A. and Singh, S. P. (2000). Evaluation of guava varieties for quality. Prog. Hort., 32(2):190-196

Singh, S., Singh S. P. and Singh, J. N. (2013). Evaluation of guava (Psidium guajava L.) cultivars under eastern U. P. conditions. Annals of Hort., 6(2): 392-394 